\title{
Effect of materialism and environmental knowledge on environmental consciousness among high school students: A study conducted in Istanbul province
}

\author{
Ahu Ergen ${ }^{1}$ \\ Barış Gençer Baykan² \\ Seda Gökçe Turan ${ }^{3}$
}

\begin{abstract}
As a result of increased industrial production and individual consumption after the industrial revolution, environmental degradation became a growing global concern. Especially when we consider the fact that young people of today will be decision makers in the future, their attitudes and behavior towards the environment will doubtlessly have great influence on natural resources and their sustainability in the future. This study explores the effect of environmental knowledge and materialism values of high school students on environmental consciousness. Subsequently, it is explored whether there is a differentiation in materialism, environmental knowledge and environmental consciousness according to gender and pre-school knowledge level of the students. The convenience sampling method, multiple regression analysis and t-test were applied to the data obtained from the sample of $101112^{\text {th }}$ grade students in Istanbul. The outcomes of the study shows that environmental knowledge and materialism variables are meaningful in explaining environmental consciousness.
\end{abstract}

Keywords: Materialism; Environmental consciousness; Environmental knowledge; High-school students; Regression analysis

\section{Introduction}

Environmental degradation and depletion of limited resources is a global problem today. Some scholars claim that the environment will be the most discussed issue in the future among states, organizations and consumers and this discussion will become very influential on the opinions and behavior of individuals and societies (do Paco and Raposo, 2008). There are demographical, external (institutional, economic, social and cultural) and internal (motivation, awareness, values,

\footnotetext{
${ }^{1}$ Dr., Bahcesehir University, Vocational School, Marketing, ahu.ergen@bahcesehir.edu.tr

2 Assist. Prof. Dr., Yeditepe University, Faculty of Economics and Administrative Sciences, Public Administration, baris.baykan@yeditepe.edu.tr

3 Instructor, Bahcesehir University, Vocational School of Health Services, Child Care and Youth Services, sedagokce.turan@,bahcesehir.edu.tr
} 
Ergen, A., Baykan, B. G., \& Turan, S. G. (2015). Effect of materialism and environmental knowledge on environmental consciousness among high school Students: A study conducted in Istanbul province. International Journal of Human Sciences, 12(1), 511-526. doi: 10.14687/iihs.v12i1.3130

attitudes, emotions, responsibilities and priorities etc.) factors that are thought to have positive or negative impact on environmental consciousness, which is the antecedent of environmentalist behavior (Kollmuss and Agyeman, 2002). In this study materialism and environmental knowledge are considered to be internal factors and they are analyzed among a sample of high school students.

Capitalist economical system and globalization effect consumers' behavior such as being happy by consuming, seeing material assets as means of success and prestige or gaining a place in society with values that certain brands represent. Studying what young people think and feel about the environment is very important in gaining clues about the future (Meinhold and Malkus, 2005). Meanwhile, since nature will be inherited by young people, there is a need going beyond the argument that they should be automatically interested in protecting the environment and nature. To study how informed they are on environmental issues and under which circumstances they can develop environmentalist attitudes and behavior gained more importance for both today and the future (Ergen et al., 2013).

In this study conducted with high school students, the effect of materialism values and environmental knowledge on environmental consciousness and whether these variables change according to gender and pre-school education level is analyzed.

\section{Materialism}

Philosophically "materialism" means that nothing can exist without matter and its movements. In Oxford English Dictionary, materialism is defined in its popular meaning: "devotion to material desires and needs, to the neglect of spiritual matters; a way ofopinion, tendency and life, based entirely on material interests" (Richins and Dawsons, 1992). Belk (1985) defines it as "the importance associated with material assets by the consumer." At the highest level of materialism, the assets that are owned are at the center of the individual's life and constitute the main source of satisfaction or dissatisfaction. According to Belk (1985) materialism includes character traits such as jealousy, possessiveness, ambition and stinginess.

Although there are various opinions on materialism and the environment in the literature, there is a general emphasis on the negative effects of materialism on the environment (depleting resources, pollution and waste). Experts often mention the fact that companies that are solely focused on reaching their global goals fuel worldwide materialism, harm sustainable resources and damage the 
Ergen, A., Baykan, B. G., \& Turan, S. G. (2015). Effect of materialism and environmental knowledge on environmental consciousness among high school Students: A study conducted in Istanbul province. International Journal of Human Sciences, 12(1), 511-526. doi: 10.14687/ijhs.v12i1.3130

ecological system while they support economic development (Strizhakova and Coulter, 2013). Some assert that materialism in market economies harm the environment (Porritt, 1984), and that materialist values conflict with environmental protection values because they are highly related to negative attitudes towards the environment and little related to the subjects of environment and ecology (Slater, 1997; Kasser and Ahuvia, 2002). There are studies revealing that highly materialistic individuals are less conscious about the environment, attend activities that aim to protect the environment less often and have greater ecological footprints (Strizhakova ve Coulter; 2013). Materialism is generally considered a pro-consumption value while environmentalism is associated with protection-oriented and anti-consumption values (Banerjee and McKeage, 1994). Bhagwati (1993) contrarily claims that economic growth will not increase but solve environmental problems.

From the social point of view, materialism's effect on interpersonal relationships and whether it contributes to identity creation and preservation is discussed frequently (Belk, 1985). Bredemeier and Toby (1960) indicate that materialism leads to many social problems while other researchers state that material values affect the perception of happiness and ego of the individual (Killbourne and Pickett, 2008).

From a psychological point of view, the prevailing opinion is that materialism is a result of high level of unsatisfied psychological needs (establishing a healthy ego, healthy social relations etc.). When one or more of these needs are not met, insecurity results and people turn to material assets in order to substitute them. There are also claims that reasons such as insecurity developed in childhood, growing up with a cold and distanced mother and divorced parents during childhood increases materialism in individuals (Chaplin et al., 2014; Burroughs et al., 2013). High materialism is associated with low self-esteem in young people and youngsters that have limited economic resources and low self-esteem shows higher levels of materialism than their rich peers (Chaplin et al., 2014). Burroughs et al. (2013) asserted that materialism is a value that has multiple negative outcomes and is becoming widespread in society, and their study on reducing materialism focused on increasing self-esteem, highlighting experiential consumption rather than consumption of tangible goods, pro-society sharing and healthy social development in children. Another study on the relationship between insecurity and materialism claims that developmental (stemming from early childhood experiences), personal (basic psychological needs, self-doubt, pride etc.), social (social relations and discomfort in public) and existential (fear of death) insecurity contributes to materialism (Rindfleisch et al., 2009). According to Burroughs et al. (2013) individuals that have a 
Ergen, A., Baykan, B. G., \& Turan, S. G. (2015). Effect of materialism and environmental knowledge on environmental consciousness among high school Students: A study conducted in Istanbul province. International Journal of Human Sciences, 12(1), 511-526. doi: 10.14687/iihs.v12i1.3130

high level of fear of their own death have higher materialistic tendencies and lower concern of the environment. It was found that materialistic individuals develop close relationships with brands as a result of existential insecurity. There are findings that imply that childhood period materialism prevents children from becoming happy, healthy and balanced adults, lead to mental problems such as anxiety and depression, cause selfish attitudes and behavior and steer them towards addictive substances like alcohol and drugs. Increasing materialism is also associated with weak domestic communication and uncontrolled TV watching in children (Burroughs et al., 2013). Chaplin and John (2010) assert that unsupportive families and peers cause children to feel insecure and this leads to the need to attach to material assets in order to increase self-esteem.

\section{Environmental knowledge}

Environmental knowledge is defined as "general knowledge of facts, concepts and relationship concerning the natural environment and its major ecosystems" (Fryxell and Lo, 2003). In Gambro and Switzky's (1996) study it was defined as "student's ability to understand and evaluate the impact of society on the ecosystem"." This knowledge shows itself in the form of recognizing environmental problems and apprehending their causes and outcomes. The oldest environmentalist behavior models imply that environmental knowledge leads to environmental awareness and concern (environmentalist attitude) and environmentalist attitude leads to environmentalist behavior (Kollmuss and Agyeman, 2002). However, knowledge is considered a necessary but insufficient precondition for developing environmentalist norms and attitudes (Bamberg and Moser, 2007). In their model, Kollmuss and Agyeman (2002) refute that there is a direct relationship between environmental knowledge and environmentalist behavior and they claim that environmental knowledge, values, attitudes and emotional interest together create a complex "environmental consciousness" which is largely dependent on personal values and personality traits but is also influenced by external factors.

A study that explored environmental activities and environmental knowledge among university students studying in different universities and departments in Finland and analyzed whether there was any variation in their attitudes towards nature and the environment, a meaningful relation was found between students' environmental knowledge and environmental attitudes. There was also a meaningful relationship between environmental knowledge and environmental activities, and it was concluded that male students had higher level of environmental knowledge than female students (Tikka et al., 2000). In the Netherlands, a national study was conducted among 9000 students of 15 years of age and older in 206 schools and the result was that $57 \%$ of $9^{\text {th }}$ grade students had very 
Ergen, A., Baykan, B. G., \& Turan, S. G. (2015). Effect of materialism and environmental knowledge on environmental consciousness among high school Students: A study conducted in Istanbul province. International Journal of Human Sciences, 12(1), 511-526. doi: 10.14687/ijhs.v12i1.3130

positive attitudes towards the environment while $35 \%$ indicated that they are willing to display extra effort or financial sacrifice for the environment. The study found that environmental knowledge levels of the students were generally low and concluded that the relationship between environmental knowledge, environmentalist attitudes and behavior is very weak (Kuhlemeier et al., 1999). On the west coast of the US, 848 students selected from schools in three big cities were involved in a study which concluded that environmental knowledge is an important intermediary variable between environmental attitude and behavior. Similar to the Finland study, male student in the US also earned higher scores than females in the environmental knowledge test (Meinhold and Malkus, 2005). In Turkey, a study aiming at analyzing gender differentiations of environmental attitudes among 450 high school students in the province of Erzurum found that gender effects environmental attitude in favor of female students and the respondents were found to be incompetent in transforming their environmentalist ideas into behavior (Kaya et al., 2009).

The role of education in reducing environmental degradation is a frequently mentioned issue in the environmental literature. The formal education system in Turkey offers environmental education to children starting from $1^{\text {st }}$ grade. In elementary education on the other hand, environmental education has been given since 1992 within geography classes and usually in Environment and People elective courses in the first year of high school, under titles such as the natural environment, environmental problems and energy. 'Environmental Protection', 'Environment and Scouts' and 'Consumer' student clubs and events like 'World Environment Day', 'Environmental Protection Week' and 'Forest Week' to be celebrated are mentioned in the Educational Activities for Primary Education, High Schools and Equivalents Directive (Iklim degisikligi, E-book p.15, http://cevreorman.gov.tr/ekitap/02.pdf). Moreover, with efforts to renew primary and elementary curriculums according to current agendas and work on developing syllabuses of geography and elective Environment and People-1 courses are ongoing (a.g.e, p.16). Caring and protecting the environment is also encouraged among children via three hours a week individual and collective activities offered to primary education $1^{\text {st }}, 2^{\text {nd }}$ and $3^{\text {rd }}$ grade students (a.g.e, p.16). Many primary and elementary schools develop programs that will increase environmental awareness and environmental knowledge. The Eco-Schools Program is a good example of these. The program involves a holistic school activity for the environment and the most important and cohesive factor in the program is student participation. Implemented in 53 countries, the program is an international project that aims to give environmental consciousness, environmental management and sustainable development education in schools. The Eco-Schools Program offers a guiding environmental education curriculum to schools and awards ones that achieve outstanding success 
Ergen, A., Baykan, B. G., \& Turan, S. G. (2015). Effect of materialism and environmental knowledge on environmental consciousness among high school Students: A study conducted in Istanbul province. International Journal of Human Sciences, 12(1), 511-526. doi: 10.14687/iihs.v12i1.3130

with their environmental education and program activities with an internationally recognized ecolabel of Green Flag, symbolizing environmentally friendly schools. Thus it is also a rewarding plan (wnw.eco-schools.org).

\section{Environmental consciousness}

As a result of numerous environmental disasters that occurred in the 1980's, environmental sensitivity and the idea of protecting the environment entered the agenda and brought about the concept of "environmental consciousness" in many societies. Environmental consciousness "is a measure of a person's ability to understand the nature of environmental processes and problems, her or his degree of concern for environmental quality and the extent to which he or she is committed to positive environmental behavior in everyday life (Linke, 1980; UNESCO-UNEP, 1988; Yau, 1992 cited in Yeung, 1998). According to Alsmadi (2007) environmental consciousness"efforts to protect and preserve the environment as well as advising others to behave accordingly" is influential in the formation of environmentalist attitude and behavior.

A study conducted with 310 students of Istanbul University Vocational School of Healthcare Services shows that the top three environmental factors that are perceived by the students as high or very high risk factors are; loss of wilderness, water shortages and chemical wastes (Yurtseven et al., 2010). Another study involving students of Istanbul University, Department of Business Administration, aiming to identify environmental differences, concluded that university students are not insensitive to environmental issues, that they have a level of awareness, but they do not have a strong attitude towards personal precautions for protecting the environment (Tunc et al., 2012). The study that analyzed environmental consciousness among students of the Social Sciences High School in Istanbul concluded that students had "medium level of sensitivity." A significant portion of the students indicated that they do not receive sufficient education on air pollution, water pollution, soil pollution and ecological balance within the formal education system. Opinions of the Social Sciences High School students on environmental sensitivity behavior did not differentiate meaningfully according to gender, school year, parents' education level, parents' profession and household income level (Aydin and Kaya, 2011).

These high school students who currently do not have an active role in most buying decisions will become decision makers in the future. Therefore, from the environmentally friendly consumption point of view, there are findings asserting that environmental consciousness is influential on sustainable consumption. A study that analyzed the relationship between environmental 
Ergen, A., Baykan, B. G., \& Turan, S. G. (2015). Effect of materialism and environmental knowledge on environmental consciousness among high school Students: A study conducted in Istanbul province. International Journal of Human Sciences, 12(1), 511-526. doi: 10.14687/iihs.v12i1.3130

consciousness and buying behavior in the US revealed that there is a positive relationship between education level and environmental consciousness and that environmental consciousness is a factor triggering environmentally friendly buying behavior (Mainieri et al., 1997 cited in Alsmadi, 2007). A study exploring the relationship between environmental consciousness and environmentalist buying behavior among 19-21 year olds in England found that environmental consciousness variable explains $20 \%$ of green buying behavior (Schlegelmilch et al., 1996). In Jordan, a study conducted with university students found that respondents generally have environmental concerns, are highly aware of environmental problems and yet their environmentalist attitude does not translate into willingness to buy environmentally friendly products. The findings of a study that measures environmental consciousness levels of students in the Hong-Kong education system shows that, in situations that require physical effort or compromise of personal freedoms, when they need to express their opinions or influence others, many students are not willing to play an active role in environmental protection (Yeung, 1998).

\section{Research Methodology}

The main objective of the study is to analyze the impact of environmental knowledge and materialism values of young people on their environmental consciousness. The secondary aim of the study is to find out if materialism, environmental knowledge and environmental consciousness change according to gender and pre-school education. The hypotheses and the model given in Figure-1 are developed accordingly.

Hypothesis 1: Materialism will influence environmental consciousness.

Hypothesis 2: Environmental knowledge will influence environmental consciousness.

Hypothesis 3: There is a significant difference in students' materialism due to gender.

Hypothesis 4: There is a significant difference in students' materialism due to pre-school education.

Hypothesis 5: There is a significant difference in students' environmental knowledge due to gender.

Hypothesis 6: There is a significant difference in students' environmental knowledge due to preschool education. 
Ergen, A., Baykan, B. G., \& Turan, S. G. (2015). Effect of materialism and environmental knowledge on environmental consciousness among high school Students: A study conducted in Istanbul province. International Journal of Human Sciences, 12(1), 511-526. doi: 10.14687/ijhs.v12i1.3130

Hypothesis 7: There is a significant difference in students' environmental consciousness due to gender.

Hypothesis 8: There is a significant difference in students' environmental consciousness due to pre-school education.

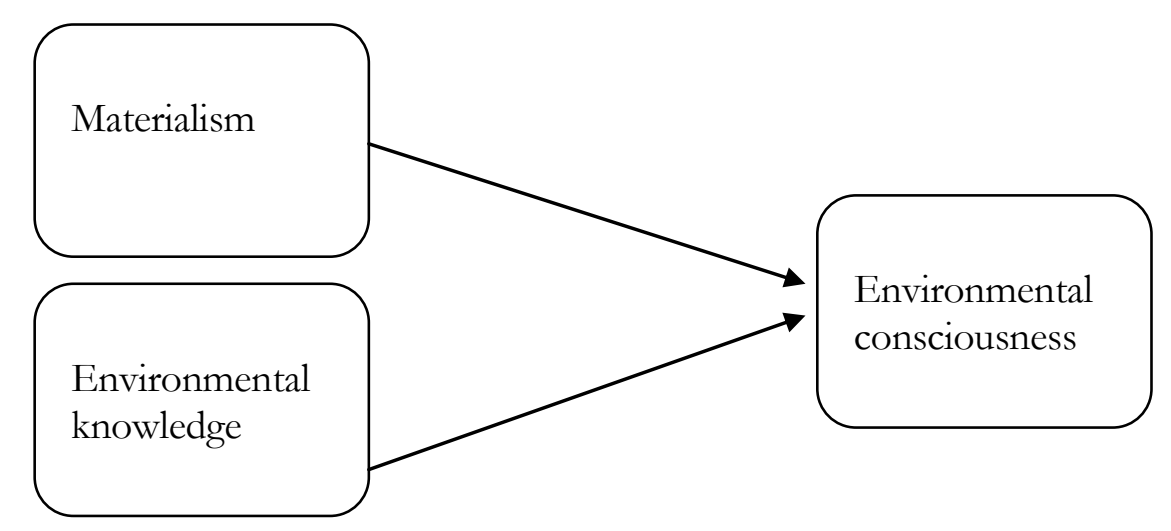

Figure 1. Research Model

The research data is obtained from $12^{\text {th }}$ grade students in the Istanbul province. With the convenience sampling method, which is a nonrandom sampling method, questionnaire based data was collected from a total of 1250 students studying in 12 different High Schools, Technical High Schools, Industrial Vocational High Schools, Female Technical Training Vocational High Schools and Anatolian High Schools in the Anatolian and European sides of Istanbul province. The complete list of high schools in Istanbul was obtained from Istanbul Directorate of National Education and the distribution of these high schools between the Anatolian and European sides was taken into consideration in order to identify schools from each central district to be visited. The implementation stage involved visiting schools, informing school administrators with presentations about the aim, content and process of the study. Appropriate times and days for students and teachers were identified. The questionnaire took about 10 minutes for each student. Among the 1250 that filled out questionnaires, 1034 was found usable, 23 were excluded after outlier calculations and as a result, analyses were conducted with 1011 questionnaires. Data was collected during March, April and May of 2012 and respondents answered the questions using 5 point Likert type scale. Questions were developed by adaptation of scales found in various sources to the aims of this study. 
Ergen, A., Baykan, B. G., \& Turan, S. G. (2015). Effect of materialism and environmental knowledge on environmental consciousness among high school Students: A study conducted in Istanbul province. International Journal of Human Sciences, 12(1), 511-526. doi: 10.14687/ijhs.v12i1.3130

\section{Findings of the Study}

The sample consists of $44.6 \%$ female and $54.3 \%$ male subjects. The portion that received preschool education are $41 \%$ while the ones that did not are $50.6 \%$. Mothers of the subjects are $3.4 \%$ uneducated, $33.7 \%$ primary school graduates, $18.7 \%$ elementary school graduates, $24.8 \%$ high school graduates, $6.1 \%$ vocational school graduates while $8.7 \%$ have undergraduate and $2.4 \%$ have graduate degrees. Fathers on the other hand, are 1.1\% uneducated, 27.6\% primary school graduates, $23.8 \%$ elementary school graduates, $27.8 \%$ high school graduates, $6.6 \%$ vocational school graduates while $8.4 \%$ have undergraduate and $2.5 \%$ have graduate degrees.

The questionnaire included six questions on materialism, five questions on environmental knowledge, ten questions on environmental consciousness and six questions on the sociodemographical characteristics of the respondents. Table 1 shows the scales used and their reliability coefficients.

Table 1. Scales used in the study and their reliability coefficients

$\begin{array}{lll}\text { Scale Developer } & \text { Item Coefficient } & \begin{array}{l}\text { Cronbach's Alpha } \\ \text { Coefficient }\end{array}\end{array}$

Materialism

Richins, M. (1987)

6

0.780

Environmental knowledge

Do Paco, A. (2010)

5

0.863

Environmental consciousness

Alsmadi, S. (2007)

10

0.893

Multiple regression method was used to test the model in Figure-1 while t-test analysis was used to test whether the variables change according to gender and pre-school education. 
Ergen, A., Baykan, B. G., \& Turan, S. G. (2015). Effect of materialism and environmental knowledge on environmental consciousness among high school Students: A study conducted in Istanbul province. International Journal of Human Sciences, 12(1), 511-526. doi: 10.14687/iihs.v12i1.3130

Table 2. Regression analysis for the effect of environmental knowledge and materialism on environmental consciousness

\begin{tabular}{llccc}
\hline Variable & $\mathbf{B}$ & $\mathbf{S E}_{\mathbf{B}}$ & Beta & T value \\
\hline Environmental knowledge & 0.347 & 0.021 & 0.416 & $16.307^{*}$ \\
Materialism & 0.378 & 0.024 & 0.397 & $15.562^{*}$ \\
$\mathrm{R}^{2}=0.48,4, * \mathrm{p}<0.05$ & & & & \\
\hline
\end{tabular}

$F$ value and its significance levels were analyzed in order to find out whether the obtained regression model is statistically meaningful or not. The F value for the model is less than 473.55, and the significance level associated with this value is less than 0.05 . Therefore, the obtained regression model is considered meaningful and can be used in estimations. Then the $\mathrm{R}^{2}$ value in Table-2 was analyzed and it was found that independent variables explain $48.4 \%$ of the dependent variable and that environmental knowledge $($ Beta $=0.416)$ and materialism (Beta $=0.397)$ have positive effect on environmental consciousness. As a result $\mathbf{H} 1$ and $\mathbf{H} 2$ hypotheses were supported and it was shown that independent variables have a positive effect on the dependent variable.

Table 3. Independent t-test analysis table for level of materialism according to gender of students

\begin{tabular}{|c|c|c|c|c|c|c|}
\hline & & $\mathbf{N}$ & Av. & $\begin{array}{c}\text { Std. } \\
\text { Deviation }\end{array}$ & $t$ value & $\begin{array}{l}\text { Significance } \\
\text { level }\end{array}$ \\
\hline \multirow{2}{*}{ Gender } & Female & 451 & 3.58 & 0.92 & \multirow{2}{*}{2,31} & \multirow{2}{*}{0.021} \\
\hline & Male & 549 & 3.44 & 0.98 & & \\
\hline
\end{tabular}

As a result of the t-test that aims to understand whether materialism changes according to gender, there was a meaningful difference between groups $(\mathrm{p}<0.05)$. Female students had higher materialism average (3.58) than male students (3.44) at a meaningful level (Table 3). H3 hypothesis is accepted. 
Ergen, A., Baykan, B. G., \& Turan, S. G. (2015). Effect of materialism and environmental knowledge on environmental consciousness among high school Students: A study conducted in Istanbul province. International Journal of Human Sciences, 12(1), 511-526. doi: 10.14687/iihs.v12i1.3130

As a result of the t-test that aims to understand whether materialism changes according to preschool education, there was not a meaningful difference between groups ( $\mathrm{p}>0.05)$. H4 hypothesis is refused.

Table 4. Independent t-test analysis table for level of environmental knowledge according to gender of students

\begin{tabular}{|c|c|c|c|c|c|c|}
\hline & & $\mathbf{N}$ & Av. & $\begin{array}{c}\text { Std. } \\
\text { Deviation }\end{array}$ & t value & $\begin{array}{l}\text { Significance } \\
\text { level }\end{array}$ \\
\hline \multirow{2}{*}{ Gender } & Female & 451 & 3.76 & 1.00 & \multirow{2}{*}{4.0} & \multirow{2}{*}{0.000} \\
\hline & Male & 549 & 3.48 & 1.14 & & \\
\hline
\end{tabular}

As a result of the t-test that aims to understand whether environmental knowledge changes according to gender, a meaningful difference was found between groups $(\mathrm{p}<0.05)$. Environmental knowledge average of female students (3.76) was higher than male students (3.48) at a meaningful level (Table 4). H5 hypothesis is accepted.

As a result of the t-test that aims to understand whether environmental knowledge changes according to pre-school education, a meaningful difference was not found between groups ( $p>0,05)$. H6 hypothesis is refused.

Table 5. Independent t-test analysis table for level of environmental consciousness according to gender of students

\begin{tabular}{|l|l|c|c|c|c|c|}
\cline { 3 - 7 } \multicolumn{2}{|c|}{} & $\mathbf{N}$ & Av. & $\begin{array}{c}\text { Std. } \\
\text { Deviation }\end{array}$ & Significance \\
t value & $\begin{array}{l}\text { vevel } \\
\text { level }\end{array}$ \\
\hline \multirow{2}{*}{ Gender } & Female & 451 & 3.99 & 0.87 & \multirow{2}{*}{5.60} & 0.000 \\
\cline { 2 - 7 } & Male & 549 & 3.67 & 0.91 & & \\
\hline
\end{tabular}

As a result of the t-test that aims to understand whether environmental consciousness level changes according to gender, a meaningful difference was found between groups $(p<0.05)$. The environmental consciousness average of female students (3.99) was higher than female students (3.49) at a meaningful level (Table 5). $\mathbf{H 7}$ hypothesis was accepted. 
Ergen, A., Baykan, B. G., \& Turan, S. G. (2015). Effect of materialism and environmental knowledge on environmental consciousness among high school Students: A study conducted in Istanbul province. International Journal of Human Sciences, 12(1), 511-526. doi: 10.14687/iihs.v12i1.3130

Table 6. Independent t-test analysis table for level of environmental consciousness according to pre-school education

\begin{tabular}{|l|l|c|c|c|c|c|}
\cline { 2 - 7 } \multicolumn{2}{|c|}{} & N & Av. & $\begin{array}{c}\text { Std. } \\
\text { Deviation }\end{array}$ & Significance \\
t value & $\begin{array}{l}\text { level } \\
\text { level }\end{array}$ \\
\cline { 2 - 7 } Pre-school education & Yes & 415 & 3.76 & 0.91 & -2.21 & 0.027 \\
\cline { 2 - 7 } & No & 512 & 3.89 & 0.88 & & \\
\hline
\end{tabular}

As a result of the t-test that aims to understand whether environmental consciousness level changes according to pre-school education, a meaningful difference was found between groups $(p<0.05)$. Environmental consciousness average of students that did not receive pre-school education (3.89) was higher than that of students that received pre-school education (3.76) at a meaningful level (Table 6). H8 hypothesis was accepted.

\section{Conclusion}

Even if it is not the only determinant, environmental knowledge is an important factor in the formation of environmental consciousness. In eliminating ever increasing environmental problems, environmental knowledge that students obtain in formal education or extracurricular activities from various sources is crucial for them to take action individually or collectively for the environment. Within the Turkish formal education system, environmental education starts at the 1 st grade. In this study, based on the finding that environmental knowledge has meaningful positive effect on environmental consciousness, Ministry of National Education and Higher Education Board are advised to add environmental education to pre-school curriculums and to encourage its continuity in a participatory way throughout education life, including higher education.

Another finding has been that environmental knowledge does not change according to pre-school education but pre-school education does have a positive effect on environmental consciousness. At this point environmental courses given during primary, elementary and high school education are thought to have effect on environmental consciousness. The fact that receiving information on environmental issues affects environmental consciousness implies that it should not be limited with school education. For instance, extracurricular information sources (public service announcements, internet games, social media, mobile games, viral advertisements etc.) used by NGOs, relevant 
Ergen, A., Baykan, B. G., \& Turan, S. G. (2015). Effect of materialism and environmental knowledge on environmental consciousness among high school Students: A study conducted in Istanbul province. International Journal of Human Sciences, 12(1), 511-526. doi: 10.14687/ijhs.v12i1.3130

public authorities and the private sector in order to increase awareness among young people in a participatory manner, will contribute to their environmental consciousness.

The finding that materialism has positive effect on environmental consciousness among young people indicates that under the current economic and social conditions of Turkey, the fact that young people give more meaning to material values than in the past, in contrast with the common belief does not inhibit their environmental sensitivities. This finding also brings to mind the possibility that the contrary results to past studies is due to the fact that high school students that the study is conducted with are not directly involved in earning money or material responsibilities. Past studies that show negative effects of materialism on environmental consciousness were conducted with adults (Slater, 1997; Kasser and Ahuvia, 2002; Banerjee and McKeage, 1994). Aiming to analyze the relationship between demographical features and materialistic tendencies of university students in Turkey and their environmental attitudes and behavior, Purutcuoglu (2008) conducted a study with 480 freshman and senior students from private and public universities in Ankara and found a medium level, meaningful and positive relationship between environmentally responsible behavior and materialist values and opinions of the environment. The findings of our study support Purutcuoglu's.

Evaluations of the gender variable show that female students' environmental consciousness, environmental knowledge and materialism averages are higher than those of male students. This finding supports a study conducted with high school students in Erzurum (Kaya et al., 2009). Studies conducted in Finland and the US, on the other hand, are in favor of male students (Tikka et al., 2000; Meinhold and Malkus, 2005). When the literature of conducted studies is reviewed, the general tendency is that women are more interested in social issues than men, independently from cultural norms and education level (Tuncer et al., 2007). Studying female and male stances towards environmental issues and elaborating on differences if applicable, can be important in designing environmental education processes, eliminating gender inequality, encouraging individual and collective environmental behavior and including gender in sustainability policy.

Evaluation of the pre-school education variable does not show any meaningful differences in environmental knowledge and materialism averages. Environmental consciousness averages, on the other hand, are found to be higher among subjects that did not receive pre-school education. This might change if environmental and sustainability subjects are included in pre-school education. Young people that did not receive pre-school education gained this consciousness through 
Ergen, A., Baykan, B. G., \& Turan, S. G. (2015). Effect of materialism and environmental knowledge on environmental consciousness among high school Students: A study conducted in Istanbul province. International Journal of Human Sciences, 12(1), 511-526. doi: 10.14687/iihs.v12i1.3130

sufficient education in later levels and doubtlessly due to extracurricular factors. It is suggested to form environmental consciousness through participatory, applied environmental education starting from pre-school level.

Social scientists claim that young people today are the most brand and consumption oriented) materialistic generation in history (Schor, 2004). Therefore, it is thought that materialism values should be studied further in the context of sustainable consumption behavior of young people. Moreover, guiding this consumption oriented generation towards green products and sustainable consumption models (recycling, reuse, green and energy efficient products, composting, et.) should be included in the agenda of educational institutions and the state. Thus, value added green product consumption will increase and sustainable development (economic, environmental and social) goals can be achieved. Prospective researchers are invited to conduct qualitative studies that can reveal the complex relationships between materialism, environmental consciousness and environmentalist behavior.

\section{Bibliography}

Alsmadi, S. (2007). Green marketing and the concern over the environment: Measuring environmental consciousness of jordanian consumers. Journal of Promotion Management. 13:(34), 339-361.

Aydin and Kaya. (2011). Sosyal bilimler lisesi ogrencilerinin cevre duyarliliklarinin degerlendirilmesi. Marmara Cografya Dergisi, 24, 229-257.

Banerjee, B., and McKeage, K. (1994). How green is my value: exploring the relationship between environmentalism and materialism. Advances in Consumer Research, 21; 147-152.

Bamberg, S., \& Moser, G. (2007). Twenty years after Hines, Hungerford and Tomera: A new metaanalysis of psycho-social determinants of pro-environmental behavior. Journal of Environmental Psychology, 27, 14-25.

Belk, R. W. (1985). Materialism: Trait aspects of living in the material world. Journal of Consumer Research, 12, 265-280.

Bhagwati, J. (1993). The case for free trade. Sci Am, 269:42-9 (November).

Bredemeier, HC., \& Toby, J. (1960). Social Problems in America: Costs and Casualties in an Acquisitive Society. New York, NY: Wiley..

Burroughs, J. E., Chaplin, L. N., Pandelaere, M., Norton, M. I., Ordabayeva, N., Gunz, A., \& Dinauer, L. (2013). Using Motivation Theory to Develop a Transformative Consumer Research Agenda for Reducing Materialism in Society. Journal of Public Policy \& Marketing, 32(1), 18-31.

Chaplin, L.N., \& John, D.R. (2010) Interpersonal influences on adolescent materialism: A new look at the role of parents and peers. Journal of Consumer Psychology, 20 (2010) 176-184. 
Ergen, A., Baykan, B. G., \& Turan, S. G. (2015). Effect of materialism and environmental knowledge on environmental consciousness among high school Students: A study conducted in Istanbul province. International Journal of Human Sciences, 12(1), 511-526. doi: 10.14687/iihs.v12i1.3130

Chaplin, L. N., Hill, R. P., \& John, D. R. (2014). Poverty and materialism: A look at impoverished versus affluent children. Journal of Public Policy \& Marketing, 33(1), 78-92.

do Paco, A. M. F., \& Raposo, M. L. B. (2008). Determining the characteristics to profile the "green" consumer: an exploratory approach. International Review on Public and Nonprofit Marketing, 5(2), 129-140.

Ergen, A., Turan, S.G., Baykan, S.G. (2013). "Gencler cevreci davranista cekimser, kiz ogrenciler erkeklerden daha duyarli”, Babcesehir Universitesi BETAM Arastirma Raporu, 13/149, 24 May.

$\underline{\text { www.ekookullar.org.tr }}$

Finisterra do Paco, A. M., \& Raposo, M. L. B. (2010). Green consumer market segmentation: empirical findings from Portugal. International Journal of Consumer Studies, 34(4), 429-436.

Fryxell, G., Lo, C. (2003). The influence of environmental knowledge and values on managerial behaviors on behalf of the environment: an empirical examination of managers in China. Journal of Business Ethics, 46, 45-59.

Gambro, J. S., \& Switzky, H. N. (1996). A national survey of high school students' environmental knowledge. The Journal of Environmental Knowledge, 27(3), 28-33.

Iklim degisikligi, http://cevreorman.gov.tr/ekitap/02.pdf

Kasser, T. and Ahuvia, A. 2002. Materialistic values and well-being in business students. European Journal of Social Psychology, 32; 137-146.

Kaya, E., Akilli, M. ve Sezek, F. (2009) Lise ogrencilerinin cevreye karsi tutumlarinin cinsiyet acisindan incelenmesi. Mehmet Akif Ersoy Universitesi Egitim Fakultesi Dergisi, 9,18; 43-54.

Kilbourne, W. \& Gregory, P. (2008). How materialism affects environmental beliefs, concern, and environmentally responsible behavior. Journal of Business Research, 61, 885-893.

Kollmus, A., \& Agyeman, J. (2002). Mind the Gap: Why do people act environmentally and what are the barriers to pro-environmental behavior?. Environmental Knowledge Research, 8(3), 239260.

Kuhlemeier, Hans., Huub Van Den Bergh \& Nijs Lagerweij (1999): Environmental knowledge, atitudes, and behavior in Dutch secondary knowledge, The Journal of Environmental Knowledge, $30: 2,4-14$.

LINKE, R.D. (1980) Environmental Knowledge in Australia (Sydney, George Allen \& Unwin Australia).

Mainieri, T., Barnett, E. G., Valdero, T. R., Unipan, J. B., and Oskamp, S. (1997). Green buying: The influence of environmental concern on consumer behavior. Journal of Social Psychology, 137(2), 189-204.

Meinhold, J.L. ve A.J. Malkus. (2005). Adolescent environmental behaviors: Can knowledge, attitudes, and self-Efficacy make a difference?. Environment and Behavior. 37(4), 511-532.

Porritt, J (1984). Seeing green: the politics of ecology explained. Basil Blackwell, Oxford, UK. (Kilbourne, W. and Pickett, G. 2007. How materialism affects environmental beliefs, concern, and environmentally responsible behavior. Journal of Business Research, doi:10.1016/j.jbusres.2007.09.016. (in press).

Purutcuoglu, E. (2008). Universite ogrencilerinin demografik ozellikleri ve materyalist egilimleri ile cevreye yonelik tutum ve davranislari arasindaki iliskinin incelenmesi. Ankara Universitesi, Fen Bilimleri Enstitusu, Unpublished PhD Thesis, Ankara. 
Ergen, A., Baykan, B. G., \& Turan, S. G. (2015). Effect of materialism and environmental knowledge on environmental consciousness among high school Students: A study conducted in Istanbul province. International Journal of Human Sciences, 12(1), 511-526. doi: 10.14687/iihs.v12i1.3130

Richins, M. L. (1987). Media, materialism, and human happiness. Advances in Consumer Research, 14(1), 352-356.

Richins, M., \& Dawson S. (1992). A consumer values orientation for materialism and its measurement: Scale development and validation. Journal of Consumer Research, 19, 303-316.

Rindfleisch, A., Burroughs, J. E., \& Wong, N. (2009). The safety of objects: Materialism, existential insecurity, and brand connection. Journal of Consumer Research, 36(1), 1-16.

Schor, J. B. (2004). Born to buy. New York: Scribner.

Schlegelmilch, B.B., G.M. Bohlen. ve A.Diamantopoulos. (1996). The link between green purchasing decisions and measures of environmental consciousness. European Journal of Marketing. 30(5), 35-55.

Slater, D (1997). Consumer culture and modernity. Polity Press, Cambridge, UK.

Strizhakova, Y. and R.A. Coulter. (2013). he "Green" Side of Materialism in Emerging BRIC and Developed Markets: The Moderating Role of Global Cultural Identity. International Journal of Research in Marketing. 30, 69-82.

Tikka, P. M., Kuitunen, M. T., \& Tynys, S. M. (2000). Effects of knowledgeal background on students' attitudes, activity levels, and knowledge concerning the environment. The journal of environmental knowledge, 31(3), 12-19.

Tuncer, G. , Ertepinar, H., Tekkaya, C. \& Sungur, S. (2007). Environmental Attitudes of Young People in Turkey: Effects of School Type and Gender. Environmental Knowledge Research, Vol:11, No:2, p: 215-233.

Tunc, A.O., Omur, G.A. ve Duren, A.Z. (2012). Cevresel Farkindalik, I.U. Siyasal Bilgiler Fakultesi Dergisi, 47; 227-246.

UNESCO-UNEP (1988) International Strategy for Action in the Field of Environmental Knowledge and Training, Moscow, Paris and Nairobi.

YAU, B.L.L.L. (1992) Environmental knowledge through the teaching and learning of geography. The Hong Kong Geographer, 9(2), pp. 12-29.

Yeung, S. \& Pui, M. (1998): Environmental consciousness among students in senior secondary schools: the case of Hong Kong. Environmental Knowledge Research, 4:3, 251-268.

Yurtseven, E., Vehid, S., Koksal, S. \& Erdogan, M.S. (2010). Istanbul Universitesi Saglik Hizmetleri Meslek Yuksekokulu Ogrencilerinin Cevresel Riskler Konusundaki Duyarliliklari, Firat Universitesi Saglik. Bilimleri Tip Dergisi, 24,3;

193-199. 